times on this route.

The authors warn

that such changes

would increase fuel consumption and $\mathrm{CO}_{2}$ emissions on this route and possibly for other flights globally, which would further drive climate change.

Nature Clim.

Change http://dx.doi. org/10.1038/nclimate2715 (2015)

\section{CLIMATE-CHANGE BIOLOGY}

\section{Bees squeezed by warming}

Bumblebee ranges are

shrinking as the world warms, suggesting that climate change is yet another factor threatening the pollinators.

A team led by Jeremy Kerr at the University of Ottawa, Canada, collated more than 420,000 observations of bumblebee species from North America and Europe between 1975 and 2010. They found that as temperatures rose, the southern limits of many bumblebee species' ranges moved north, by as much as 300 kilometres in some cases. But the northern edges of the bees' ranges stayed in place, leading to an overall contraction of the insects' habitats.

Neither pesticide usage nor changes in land use correlated with the observed shifts in the bumblebee ranges.

Science 349, 177-180(2015)

\section{BEHAVIOURAL ECOLOGY}

\section{Why bats like to perch in a pitcher}

Pitcher plants in Borneo have evolved specialized structures that attract bats, which roost inside the plants and fertilize them with their faeces.

Michael Schöner of the University of Greifswald in Germany and his colleagues bounced sonar waves off the rear inner wall of the pitcher plant Nepenthes hemsleyana and found that it reflected the sound much more clearly and strongly than did other species of pitcher plant. When they modified or removed the sound reflector, wild Hardwicke's woolly bats (Kerivoula hardwickii; pictured) took much longer to find the plant.

The authors suggest that such acoustically mediated symbiotic relationships may be more common than was thought.

Curr. Biol. http://doi.org/56c (2015)

\section{GENE THERAPY \\ Deafness can be reversed in mice}

Researchers have partially restored the hearing of deaf mice by delivering functioning genes into their ear cells.

Jeffrey Holt at Boston Children's Hospital in Massachusetts and his colleagues tested deaf mice that have mutations in the Tmc1 gene, which causes $4-8 \%$ of genetic deafness in some human populations. They injected the mice with a virus carrying the gene and found that hair cells in the inner ear which normally convert sound vibrations into electrical signals - took up and expressed the gene. The animals showed startle reflexes and brain responses to sounds.

This approach could one day complement other hearingloss therapies, such as cochlear implants and hearing aids, the authors say.

Sci. Transl. Med. 7, 295ra108 (2015)

\section{PHYSIOLOGY \\ How bear bones stay strong}

Bones weaken with inactivity in most mammals, but hibernating bears maintain theirs by suppressing

SOCIAL SELECTION Replaterien

\title{
US postdocs hope for overtime pay
}

A proposed regulation by US President Barack Obama that would extend overtime pay to millions of workers triggered fierce discussion among academics - including some who think that it could result in heftier pay for postdocs (see go.nature.com/jgckvb). If approved, the regulation would enable salaried workers who earn less than about US $\$ 50,400$ per year to receive at least 1.5 times their usual rate for every extra hour worked beyond a 40 -hour week. "This reform is a LABOR law. Give me A SINGLE compelling reason academics below $50 \mathrm{~K}$ should not be treated like other workers in this case," tweeted Francois Gould, an anatomy postdoc at Northeast Ohio Medical University in Rootstown, Ohio. But Belinda Huang, who is executive director of the National Postdoctoral Association,

DNATURE.COM

For more on popular papers: go.nature.com/7viusy headquartered in Washington DC, says that it is unclear whether the proposal would apply to postdocs and other scientists. bone turnover.

Seth Donahue at Colorado

State University in Fort Collins and his colleagues analysed blood and bone samples from 13 black bears (Ursus americanus), which hibernate for up to 6 months every year. They found lower levels of key protein markers associated with bone formation and breakdown in hibernating bears than in active ones. The concentration of a hormone that reduces bone breakdown was 15 times higher during hibernation than during active periods.

Hibernating and active bears had the same level of calcium in their blood, suggesting that bears balance bone formation with breakdown during hibernation.

J. Exp. Biol. 218, 2067-2074 (2015)

\section{Humans alter desert ecosystem}

A community of small mammals in the western United States has changed more in the past century than in the past 13,000 years, thanks to human activities.
Rebecca Terry at Oregon State University in Corvallis and Rebecca Rowe at the University of New Hampshire in Durham analysed the skeletal remains of small mammals dating back to 12,800 years ago from a large cave in Utah. They found that energy flow - a metric combining the number, size and metabolic rates of animals - in this community was largely stable up until about the late 1800 s, even during periods of rapid natural climate warming. But in the past 100 years, energy flow has dropped significantly, indicating a population surge in small animals that thrive in grassy habitats and a loss of animals in desert shrublands.

The authors suggest that this is a result of the replacement of shrublands with invasive grasses, owing to human activity, in this desert region.

Proc. Natl Acad. Sci. USA

http://dx.doi.org/10.1073/

pnas.1424315112 (2015)

\section{ONATURE.COM}

For the latest research published by Naturevisit:

www.nature.com/latestresearch 